
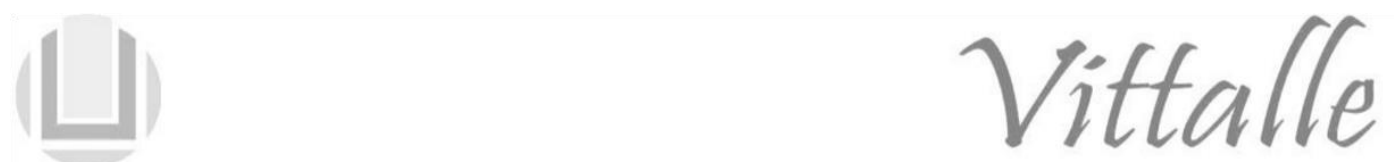

\title{
Vitamin C supplementation in cardiopulmonary bypass: a review
}

\author{
Matheus Mittmann Hennemann ${ }^{\mathrm{a}^{*}}$, Élio Barreto de Carvalho Filho ${ }^{\mathrm{b}}$ \\ aSanta Casa de Misericórdia de Porto Alegre, Hospital São Francisco, Porto Alegre, RS, Brasil \\ bUniversidade Estadual De Campinas, Faculdade de Ciências Médicas, Departamento de Cirurgia Cardíaca, \\ Campinas, SP, Brasil
}

\begin{abstract}
Histórico do Artigo
Recebido em:

10/11/2019

Aceito em:

$18 / 01 / 2020$

Keywords

Ascorbic acid; oxidative stress; cardiac surgery; cardiopulmonary bypass
\end{abstract}

Palavras-chave: Ácido ascórbico; estresse oxidativo; cirurgia cardíaca; circulação extracorpórea

\begin{abstract}
Hypovitaminosis $\mathrm{C}$ is frequent in postoperative period of surgical patients and may last for several days after surgery. The reestablishment of normal plasma ascorbate (vitamin C) levels by supplementation requires intravenous administration, which is safe and well tolerated. This antioxidant mitigates the oxidative damage produced by the insults of surgery, cardiopulmonary bypass and ischemia-reperfusion event. Ascorbate supplementation after cardiac surgery improves patient oxidative state, shortens hospital stay, streamlines wound closure and reduces incidence of postoperative atrial fibrillation. However, we think this vitamin may offer yet other benefits, especially in cardiac surgery postoperative period. The aim of this review is to evaluate recent studies on vitamin $\mathrm{C}$ supplementation in surgical patients, focusing on cardiac surgery with cardiopulmonary bypass, and to discuss the next steps regarding the potential benefits that can be obtained from the implementation of this conduct in the hospital routine.
\end{abstract}

\section{Suplementação de vitamina $\mathrm{C}$ na circulação extracorpórea:} uma revisão

\section{RESUMO}

A hipovitaminose $\mathrm{C}$ é frequente no pós-operatório de pacientes cirúrgicos e pode durar vários dias após a cirurgia. $\mathrm{O}$ restabelecimento dos níveis plasmáticos normais de ascorbato (vitamina C) por suplementação requer administração intravenosa, o que é seguro e bem tolerado. Esse antioxidante mitiga os danos oxidativos produzidos pelos insultos da cirurgia, da circulação extracorpórea e do evento de isquemia-reperfusão. A suplementação de vitamina $\mathrm{C}$ após cirurgia cardíaca melhora o estado oxidativo dos pacientes, reduz o tempo de internação hospitalar, auxilia o fechamento de feridas e diminui incidência de fibrilação atrial pós-operatória. No entanto, acreditamos que essa vitamina possa oferecer ainda outros benefícios. O objetivo desta revisão é avaliar estudos recentes sobre suplementação de vitamina $\mathrm{C}$ em pacientes cirúrgicos, com foco em cirurgia cardíaca com circulação extracorpórea, e discutir as próximas etapas sobre os possíveis benefícios que podem ser obtidos com a implementação dessa conduta na rotina hospitalar.

\section{Introduction}

Vitamin $\mathrm{C}$ is the major water-soluble antioxidant of the organism, and acts as the first defense against free radicals on human plasma $(1,2)$. This compound acts directly as scavenger or in the regeneration of other antioxidants, and also presents anti-inflammatory effects, potentializes catecholamine effects and protects microcirculation $(3,4)$.

Hypovitaminosis $\mathrm{C}$ is frequent in postoperative period of surgical patients and may last for several days (5). The reestablishment of normal plasma ascorbate levels by supplementation requires administration of intravenous (IV) doses of 2-3 grams per day, which is safe and well tolerated (6,7). Vitamin C supplementation improves patient oxidative state, shortens hospital stay and streamlines wound closure $(8,9)$.

\footnotetext{
*Corresponding author: matheusmhennemann@gmail.com (Hennemann M.M.)
} 
Pre- or postoperative supplementation has been studied as complementary therapy in patients undergoing cardiac surgery with cardiopulmonary bypass $(\mathrm{CPB})$. The rationale in these cases is that this antioxidant mitigates the oxidative damage produced by the insults of surgery, CPB and ischemia-reperfusion event (10). Studies have already shown a lower incidence of postoperative atrial fibrillation through vitamin $\mathrm{C}$ supplementation (11). However, this vitamin may offer yet other benefits.

The aim of this systematic review is to evaluate recent studies on vitamin $\mathrm{C}$ supplementation in surgical patients, focusing on cardiac surgery with $\mathrm{CPB}$, and to discuss the next steps regarding the potential benefits that can be obtained from the implementation of this conduct in the hospital routine.

\section{Methods}

\subsection{Literature search strategy}

The Preferred Reporting Items for Systematic reviews and Meta-Analyses (PRISMA) statement guidelines were followed in this systematic review (12). Publications were searched in the PubMed, MEDLINE and Google Scholar databases up to November 2019. The Medical Subject Headings (MeSH) terms and keywords used to identify articles included "vitamin C", "ascorbic acid", "ascorbate", "cardiac surgery", and "cardiopulmonary bypass." All search terms were combined with Boolean operators and searched as both key words and $\mathrm{MeSH}$ terms to ensure maximal sensitivity. Articles related to the topic and keywords in the literature search were included in the review. Limits were placed to only include studies written in the English, Portuguese or Spanish languages. After excluding articles based on title or abstract, the following full text articles that were selected had their reference lists searched for any potential further articles to be included in this review.

\section{Literature review}

\subsection{Vitamin c metabolism}

Vitamin C (ascorbate or ascorbic acid) is a water-soluble organic compound not synthesized by humans. The recommended daily intake for adults is $75-100 \mathrm{mg} / \mathrm{day}$ to maintain plasma concentration around 50-60 $\mu \mathrm{mol} / \mathrm{L}(2,5)$. Higher concentrations are found in leukocytes, nerve cells, eyes and adrenal gland (2). Transport in the body occurs through cell membrane expressed transporters, especially SVCT1 and SVCT2 $(13,14)$.

Vitamin $\mathrm{C}$ is the body's main water-soluble antioxidant, acting as the first defense against free radicals such as superoxide $\left(\mathrm{O}_{2}^{-}\right)$and peroxynitrite $\left(\mathrm{ONOO}^{-}\right)$in plasma (1). It acts by donating electrons to free radicals, forming the ascorbate radical, and preventing damage to macromolecules and DNA (2). Such protection occurs via inhibition and attenuation of free radical damage to such molecules (10).

Dismutation of two ascorbate radical molecules results in one ascorbate molecule and one dehydroascorbate (DHA) molecule. The irreversible conversion of DHA to 2,3diketogulonic acid generates, among other metabolites, oxalate, which is excreted by the kidneys (15) (Figure 1). Renal damage caused by hyperoxaluria takes months to settle, which assures safety in the administration of high doses of vitamin $\mathrm{C}$.

Vitamin $\mathrm{C}$ acts as a cofactor for more than 15 enzymes, including the synthesis of norepinephrine, dopamine, vasopressin and collagen. In addition, it acts in the regeneration of other antioxidants ( $\alpha$-tocopherol (vitamin E), glutathione and urate), as 
an anti-inflammatory agent (through inhibition of $\mathrm{NF}-\kappa \mathrm{B}$ and proinflammatory mediators), increasing sensitivity to catecholamines and protecting microcirculation (decreasing endothelial permeability and avoiding edema) $(3,4)$ (Table 1).

Table 1 - Pleiotropic effects of vitamin $\mathrm{C}$. NOX = nicotinamide adenine dinucleotide phosphate oxidase; NF- $\kappa \mathrm{B}=$ nuclear factor $-\kappa \mathrm{B}$. Modified from Oudemans-van Straaten et al. (3) and Spoelstra et al. (4).

\begin{tabular}{|c|c|}
\hline Effects & Mechanism of action \\
\hline \multirow[t]{3}{*}{ Antioxidative } & Direct radical scavenger (superoxide, peroxynitrite) \\
\hline & Regeneration of antioxidants ( $\alpha$-tocopherol, glutathione, urate) \\
\hline & Less free radical production (prevention of NOX activation) \\
\hline Cofactor or cosubtrate biosynthesis & $\begin{array}{l}\text { Essential to hydroxylases and monooxygenases of dopamine, } \\
\text { norepinephrine, vasopressin and collagen }\end{array}$ \\
\hline Anti-inflammatory & $\begin{array}{l}\text { Inhibition of } \mathrm{NF}-\mathrm{\kappa B} \text { and reduction in proinflammatory } \\
\text { mediators }\end{array}$ \\
\hline Increase of catecholamine sensitivity & Binding to adrenergic receptors \\
\hline \multirow[t]{2}{*}{ Microcirculation protection } & $\begin{array}{l}\text { Decrease endothelial permeability (prevention of eNOS } \\
\text { uncoupling) }\end{array}$ \\
\hline & $\begin{array}{l}\text { Improve microcirculatory patency (reduction of leukocyte } \\
\text { stickiness and sludging) }\end{array}$ \\
\hline
\end{tabular}

Ascorbic acid may also exhibit pro-oxidant activity $(4,16)$. Vitamin $\mathrm{C}$ reacts with metal irons in the called Fenton reaction. Ions such as $\mathrm{Fe}^{3+}$ and $\mathrm{Cu}^{3+}$ are reduced by ascorbic acid, and free radicals are generated. The deleterious effects of superoxide and hydrogen peroxide formed in this reaction seem to be unimportant under physiological conditions. Moreover, the majority of in vitro and in vivo studies show a predominance of the antioxidant action of vitamin $\mathrm{C}$ (17).

\subsection{Deficiency}

Vitamin C deficiency is frequent in critically ill patients, and may be a result of the association of lower intake and higher demand. Studies have reported that critically ill patients presented decreased vitamin $\mathrm{C}$ concentration following a primary insult, being it an ischemia-reperfusion event, sepsis, severe burn or multiple organ failure (18).

Fukushima et al. (10) reported decreased vitamin C plasma concentration in patients after gastrectomy for gastric cancer. The deficiency remained significant 7 days after surgery and was attributed to the result of redistribution in the body and elevated consumption. Ballmer et al. (19) showed a $71 \%$ decrease in ascorbate plasma concentration after cardiac surgery, especially after CPB. Rodemeister et al. (20) also reported a decrease in vitamin $\mathrm{C}$ plasma concentration, especially after $\mathrm{CPB}$, and low levels remained up to 7 days after cardiac surgery.

Ascorbate deficiency after surgery does not occur due to increase renal excretion or hemodilution (10). Studies argue that organism increase the demand of vitamin $\mathrm{C}$, particularly more intense oxidative stress situations (5). In this scenario, pre- or postoperative supplementation has been studied as a way to prevent a decrease in plasma vitamin $\mathrm{C}$ levels and maintain the body's antioxidant capacity after a stressful event.

\subsection{Supplementation}

Vitamin C supplementation in critically ill patients should be intravenously administered once enteral administration has absorption limits not sufficient to elevate plasma levels (4). A study showed that 2 g/day IV doses are required for plasma 
replacement to adequate levels in critically ill patients (6), while another reported lower values, about $500 \mathrm{mg} / \mathrm{day}$, to achieve the same effect (5).

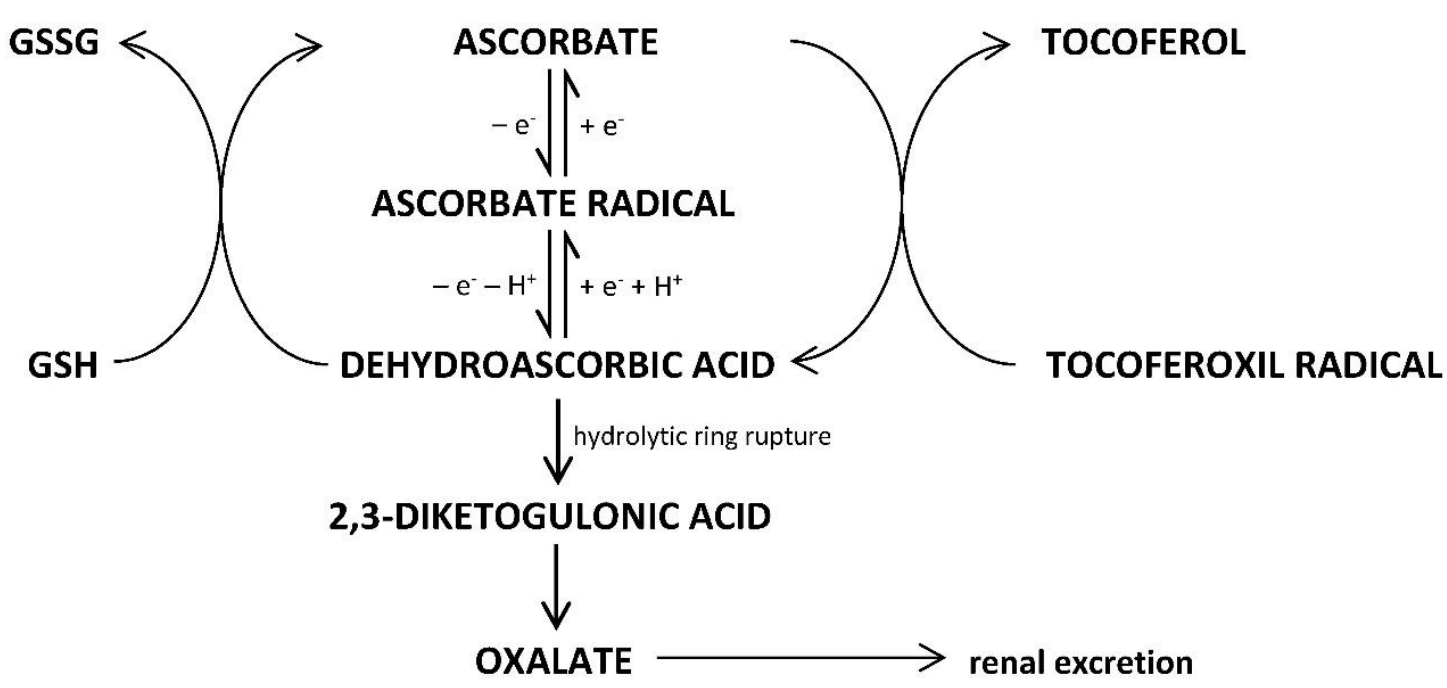

Figure 1 - Vitamin C (or ascorbate) metabolism. Ascorbate acts as an electron donor to free radicals, producing ascorbate radical (or semihydroascorbic acid). Ascorbate radical can lose a second electron to form dehydroascorbic acid (DHA) by acting again as an electron donor. DHA may be reduced back to vitamin $\mathrm{C}$ or undergoes hydrolysis with irreversible ring rupture to form 2,3-diketogulonic acid. Oxalate, one of the metabolic products of 2,3-diketogulonic acid, is excreted in the urine.

As for the safety of vitamin $\mathrm{C}$ administration, it can be said that even dosages above the necessary for a given patient will not be harmful, since their metabolites are easily eliminated by the body (Figure 1). Doses around $1500 \mathrm{mg} / \mathrm{kg} /$ day were well tolerated in cancer patients (7), as well as overdoses of 101-224 g/day in burn patients (9). Most early studies on vitamin $\mathrm{C}$ supplementation in patients undergoing cardiac surgery use intravenous dosing of $2 \mathrm{~g}$ preoperatively and 1-2 g/day postoperatively (15), demonstrating safety about the administration of this vitamin.

The best timing for vitamin $\mathrm{C}$ administration is still unknown. Jouybar et al. (21) evaluated the effects of administering one dose (3g) 12 to $18 \mathrm{~h}$ prior cardiac surgery and another dose during anesthetic induction. Emadi et al. (22) administered $5 \mathrm{~g}$ of vitamin $\mathrm{C}$ before anesthesia induction and another $5 \mathrm{~g}$ in the cardioplegic solution. Dingchao et al. (8) studied the effects of two high doses $(125 \mathrm{mg} / \mathrm{kg})$, the first $30 \mathrm{~min}$ before CPB and the second during $\mathrm{CPB}$, at the time of aortic declamping. The interesting approach of administration before coronary reperfusion was also studied with vitamin $\mathrm{E}$ supplementation (23). Safaei et al. (24) added vitamin C (25 mg/kg) or grape seed extract in the CPB prime and demonstrated impressive improvement in several postoperative parameters in both groups comparing to the control group in patients undergoing coronary artery bypass grafting (CABG). Other studies have evaluated pre- and postoperative administration, with a higher dosage on the day before surgery $(2 \mathrm{~g})$ and continued supplementation $(1 \mathrm{~g} /$ day $)$ for a few days after the procedure $(15,25)$. Since the decrease in plasma vitamin $\mathrm{C}$ levels occurs in the first hours after surgery due to the large formation of reactive species soon after reperfusion, late administration appears to be ineffective $(4,19)$. However, further randomized clinical trials are necessary to assess optimal timing and dosing administration of this antioxidant to prevent ischemia-reperfusion damage. 


\subsection{Ischemia-reperfusion}

During the ischemia period, cellular damage occurs due to depletion of energy and oxygen stores. At organ reperfusion, this initial damage is exacerbated, especially in highly active organs such as the brain and the heart (7). The enormous generation of reactive oxygen (ROS) and nitrogen (RNS) species occurs by inducing enzymes, such as NOX and eNOS, by uncoupling mitochondrial oxidative phosphorylation and other reactions. The reactive species generated, when they overcome the body's antioxidant defenses, may generate cellular damage that manifests as increased vascular permeability, leukocyte and platelet adhesion, local inflammation and vasodilation, and attenuation of catecholamine responsiveness $(20,26)$.

Vitamin $\mathrm{C}$ is the first plasma antioxidant to combat reactive species, acting before other antioxidants such as vitamin E ( $\alpha$-tocopherol) and glutathione (GSH) (2,27). Given this, and that an acute depletion in plasma vitamin $\mathrm{C}$ concentration occurs after surgical procedures $(5,19,20)$, the administration of vitamin $\mathrm{C}$ in the context of the damage generated by ischemia-reperfusion has been studied in order to restore the body's antioxidant defenses. In vitro studies have shown that vitamin $\mathrm{C}$ was able to decrease $\mathrm{O}_{2}{ }^{-}$ , $\mathrm{H}_{2} \mathrm{O}_{2}$ and $\mathrm{ONOO}^{-}$production, prevent $\mathrm{NOX}$ activation, decrease endothelial permeability and improve myocyte resistance to cell death $(3,28)$. In addition, human studies have confirmed that vitamin $\mathrm{C}$ supplementation reduce microcirculatory flow dysfunction induced by reactive species, reduce vascular leakage and attenuate decreased catecholamine responsiveness $(3,7)$.

\subsection{Cardiopulmonary bypass and cardiac surgery}

Patients undergoing cardiac surgery with CPB have their heart exposed to ischemiareperfusion damage after aortic declamping. In addition, the body also suffers from the oxidative stress generated by the procedure and from the systemic inflammatory response syndrome (SIRS) (29). Several studies have evaluated the effects of vitamin C supplementation in patients undergoing CPB. Dingchao et al. (8) reported protective effects of high-dose vitamin $\mathrm{C}$ administered before $\mathrm{CPB}$ and at the time of aortic declamping. Patients had lower oxidative damage, lower myocardial damage, better postoperative cardiac index and shorter hospital stay. Emadi et al. (22) observed improved ventricular function $72 \mathrm{~h}$ after surgery and reduced length of intensive care unit stay. Two other studies showed increased levels of plasma malondialdehyde (MDA), a marker of lipid peroxidation, after CPB $(10,30)$. On the other hand, others studies showed that ascorbic acid supplementation was not able to decrease the incidence of acute renal failure after CPB $(31,32)$.

Rodemeister et al. (10) argued that the decrease in plasma vitamin C concentration sustained for 6 days after surgery is due to the body's high demand for this antioxidant. Moreover, they suggest that there would be 3 insults responsible for the higher consumption of ascorbate: 1) the stress of the surgery itself 2) the damage of ischemiareperfusion event and 3) the period of convalescence, a sustained stress level in the first postoperative days. Several authors have evaluated the effects of vitamin $\mathrm{C}$ administration in conjunction with other compounds such as vitamin $\mathrm{E}$ ( $\alpha$-tocopherol) $(33,34)$, allopurinol and acetylcysteine $(35,36)$ and omega $3(37)$, looking for synergistic effects.

\subsection{Postoperative atrial fibrillation}

Atrial fibrillation $(\mathrm{AF})$ is the most common arrhythmia after cardiac surgery, affecting 
up to $41 \%$ of patients undergoing coronary artery bypass grafting (CABG) and up to $60 \%$ of patients undergoing CABG + valve replacement $(11,38)$. The occurrence of postoperative AF prolong intensive care unit time, increase risk of stroke, reoperation for bleeding and cerebral complications, decreases patient survival rate and generate higher hospital cost $(25,39)$.

The beneficial effects of vitamin $\mathrm{C}$ in reducing postoperative $\mathrm{AF}$ have been described by several studies $(11,25,39)$. Vitamin $\mathrm{C}$ is thought to minimize the damage caused by $\mathrm{ONOO}^{-}$in the cell membrane and cardiomyocyte function, protecting the heart against damage to this free radical that is associated with AF. The synergistic effect of vitamin $\mathrm{C}$ with $\beta$-blockers has also been reported, probably acting in direct protection against ischemia-reperfusion damage and increasing responsiveness to catecholamines $(3,40)$.

$\mathrm{Hu}$ et al. (11) evaluated the efficacy and safety of vitamin $\mathrm{C}$ in preventing postoperative AF in adult patients after cardiac surgery. The meta-analysis reported the safety of this therapy, as well as lower postoperative AF. Vitamin C supplementation had no impact in the length of intensive care unit and hospital stay. Rodrigo et al. (41) reported a safe, welltolerated and low-cost regimen of antioxidant supplementation with polyunsaturated fatty acids ( $2 \mathrm{~g} /$ day), vitamins C (1 g/day) and vitamin E (400 IU/day. Patients received antioxidants 2 days before cardiac surgery with CPB until hospital discharge. Treatment resulted in a $66 \%$ reduction in AF occurrence and lower levels of inflammation and oxidative stress biomarkers (41).

Postoperative AF is a persistent complication following cardiac surgery $(39,42)$. Giving the relevance and the impact of this event in the cardiac surgery postoperative period, ascorbate supplementation should be considered to these patients. Considering heart manipulation during the procedure, the type of surgery (CAGB, valve replacement, aortic surgery) shall be assessed in postoperative FA studies. Randomized controlled trials must be performed to elucidate the effects of ascorbate supplementation alone, as well as the most indicated patient profile to receive this regimen.

\section{Conclusion}

Current evidence demonstrates potential and proven benefits of vitamin $\mathrm{C}$ supplementation in patients undergoing cardiac surgery. The dosage, timing of administration and patients best suited for this additional therapy have yet to be studied through randomized controlled trials. However, vitamin $\mathrm{C}$ administration to patients undergoing cardiopulmonary bypass is an additionally beneficial option in modulating the response to surgery and ischemia-reperfusion, besides being a safe, inexpensive and affordable strategy.

\section{Conflict of interest}

Authors declare no conflict of interest.

\section{References}

1. Haramaki N, Stewart DB, Aggarwal S, Ikeda H, Reznick AZ, Packer L. Networking antioxidants in the isolated rat heart are selectively depleted by ischemia-reperfusion. Free Radic Biol Med 1998; 25(3): 329-39.

2. Padayatty SJ, Levine M. Vitamin C: the known and the unknown and Goldilocks. Oral Dis 2016; 22(6): 463-93.

3. Oudemans-van Straaten HM, Spoelstra-de Man AM, de Waard MC. Vitamin C revisited. Crit Care 
2014; 18(4): 460 .

4. Spoelstra-de Man AME, Elbers PWG, Oudemans-Van Straaten HM. Vitamin C: should we supplement? Curr Opin Crit Care 2018; 24(4): 248-55.

5. Fukushima R, Yamazaki E. Vitamin C requirement in surgical patients. Curr Opin Clin Nutr Metab Care 2010; 13(6): 669-76.

6. de Grooth HJ, Manubulu-Choo WP, Zandvliet AS, Spoelstra-de Man AME, Girbes AR, Swart EL, et al. Vitamin C Pharmacokinetics in Critically Ill Patients: A Randomized Trial of Four IV Regimens. Chest 2018; 153(6): 1368-77.

7. Spoelstra-de Man AME, Elbers PWG, Oudemans-van Straaten HM. Making sense of early high-dose intravenous vitamin $C$ in ischemia/reperfusion injury. Crit Care 2018; 22(1): 70.

8. Dingchao H, Zhiduan Q, Liye H, Xiaodong F. The protective effects of high-dose ascorbic acid on myocardium against reperfusion injury during and after cardiopulmonary bypass. Thorac Cardiovasc Surg 1994; 42(5): 276-8.

9. Buehner M, Pamplin J, Studer L, Hughes RL, King BT, Graybill JC, et al. Oxalate Nephropathy After Continuous Infusion of High-Dose Vitamin $\mathrm{C}$ as an Adjunct to Burn Resuscitation. J Burn Care Res 2016; 37(4): e374-9.

10. Rodemeister S, Duquesne M, Adolph M, Nohr D, Biesalski HK, Unertl K. Massive and long-lasting decrease in vitamin $\mathrm{C}$ plasma levels as a consequence of extracorporeal circulation. Nutrition 2014; 30(6): 673-8.

11. Hu X, Yuan L, Wang H, Li C, Cai J, Hu Y, et al. Efficacy and safety of vitamin C for atrial fibrillation after cardiac surgery: A meta-analysis with trial sequential analysis of randomized controlled trials. Int J Surg 2017; 37: 58-64.

12. Liberati A, Altman DG, Tetzlaff J, Mulrow C, Gøtzsche PC, Ioannidis JP, et al. The PRISMA statement for reporting systematic reviews and meta-analyses of studies that evaluate health care interventions: explanation and elaboration. J Clin Epidemiol 2009; 62(10): e1-34.

13. Wilson JX. Regulation of vitamin C transport. Annu Rev Nutr 2005; 25: 105-25.

14. Liang WJ, Johnson D, Jarvis SM. Vitamin C transport systems of mammalian cells. Mol Membr Biol 2001; 18(1): 87-95.

15. Hill A, Wendt S, Benstoem C, Neubauer C, Meybohm P, Langlois P, et al. Vitamin C to Improve Organ Dysfunction in Cardiac Surgery Patients-Review and Pragmatic Approach. Nutrients 2018;10 (8).

16. Putchala MC, Ramani P, Sherlin HJ, Premkumar P, Natesan A. Ascorbic acid and its pro-oxidant activity as a therapy for tumours of oral cavity -- a systematic review. Arch Oral Biol 2013; 58(6): 56374.

17. Carr A, Frei B. Does vitamin C act as a pro-oxidant under physiological conditions? FASEB J 1999; 13(9): 1007-24.

18. Zhang M, Jativa DF. Vitamin C supplementation in the critically ill: A systematic review and metaanalysis. SAGE Open Med 2018; 6: 2050312118807615.

19. Ballmer PE, Reinhart WH, Jordan P, Bühler E, Moser UK, Gey KF. Depletion of plasma vitamin C but not of vitamin E in response to cardiac operations. J Thorac Cardiovasc Surg 1994; 108(2): 20.

20. Marczin N, El-Habashi N, Hoare GS, Bundy RE, Yacoub M. Antioxidants in myocardial ischemiareperfusion injury: therapeutic potential and basic mechanisms. Arch Biochem Biophys 2003; 420(2): 222-36.

21. Jouybar R, Kabgani H, Kamalipour H, Shahbazi Sh, Allahyary E, Rasouli M, et al. The Perioperative Effect of Ascorbic Acid on Inflammatory Response in Coronary Artery Bypass Graft Surgery; A Randomized Controlled Trial Coronary Artery Bypass Graft Surgery. Int Cardiovasc Res J 2012; 6(1): 5.

22. Emadi N, Nemati MH, Ghorbani M, Allahyari E. The effect of high-dose vitamin c on biochemical markers of myocardial injury in coronary artery bypass surgery of myocardial injury in coronary artery bypass surgery. Braz J Cardiovasc Surg 2019; 34(5): 8.

23. Canbaz S, Duran E, Ege T, Sunar H, Cikirikcioglu M, Acipayam M. The effects of intracoronary administration of vitamin $\mathrm{E}$ on myocardial ischemia-reperfusion injury during coronary artery surgery. Thorac Cardiovasc Surg 2003; 51(2): 57-61.

24. Safaei N, Babaei H, Azarfarin R, Jodati AR, Yaghoubi A, Sheikhalizadeh MA. Comparative effect of 
grape seed extract (Vitis vinifera) and Ascorbic Acid in Oxidative Stress Induced by On-Pump Coronary Artery Bypass Surgery. Ann Card Anaesth 2017; 20(1): 45-51.

25. Rebrova TIu, Shipulin VM, Afanas'ev SA, Vorob'eva EV, Kiǔko OG. [The experience of the application of ascorbic acid as antioxidant after coronary artery surgery with use of cardiopulmonary bypass]. Kardiologiia 2012; 52(7): 73-6.

26. Salameh A, Dhein S. Strategies for Pharmacological Organoprotection during Extracorporeal Circulation Targeting Ischemia-Reperfusion Injury. Front Pharmacol 2015; 6(296): 12.

27. Cavarocchi NC, England MD, O'Brien JF, Solis E, Russo P, Schaff HV, et al. Superoxide generation during cardiopulmonary bypass: is there a role for vitamin E? J Surg Res 1986; 40(6): 519-27.

28. Tanaka H, Lund T, Wiig H, Reed RK, Yukioka T, Matsuda H, et al. High dose vitamin C counteracts the negative interstitial fluid hydrostatic pressure and early edema generation in thermally injured rats. Burns 1999; 25(7): 569-74.

29. Hessel EA. What's New in Cardiopulmonary Bypass. J Cardiothorac Vasc Anesth 2019; 33(8): 2296326.

30. Tangney CC, Hankins JS, Murtaugh MA, Piccione W. Plasma vitamins E and C concentrations of adult patients during cardiopulmonary bypass. J Am Coll Nutr 1998; 17(2): 162-70.

31. Antonic M. Effect of Ascorbic Acid on Postoperative Acute Kidney Injury in Coronary Artery Bypass Graft Patients: A Pilot Study. Heart Surg Forum 2017; 20(5): E214-E8.

32. Amini S, Robabi HN, Tashnizi MA, Vakili V. Selenium, Vitamin C and N-Acetylcysteine do not Reduce the Risk of Acute Kidney Injury after Off-Pump CABG: a Randomized Clinical Trial. Braz J Cardiovasc Surg 2018; 33(2): 129-34.

33. Westhuyzen J, Cochrane AD, Tesar PJ, Mau T, Cross DB, Frenneaux MP, et al. Effect of preoperative supplementation with alpha-tocopherol and ascorbic acid on myocardial injury in patients undergoing cardiac operations. J Thorac Cardiovasc Surg 1997; 113(5): 942-8.

34. Gunes T, Bozok S, Kestelli M, Yurekli I, Ilhan G, Ozpak B, et al. $\alpha$-tocopherol and ascorbic acid in early postoperative period of cardiopulmonary bypass. J Cardiovasc Med (Hagerstown) 2012; 13(11): 691-9.

35. Sisto T, Paajanen H, Metsä-Ketelä T, Harmoinen A, Nordback I, Tarkka M. Pretreatment with antioxidants and allopurinol diminishes cardiac onset events in coronary artery bypass grafting. Ann Thorac Surg 1995; 59(6): 1519-23.

36. Angdin M, Settergren G, Starkopf J, Zilmer M, Zilmer K, Vaage J. Protective effect of antioxidants on pulmonary endothelial function after cardiopulmonary bypass. J Cardiothorac Vasc Anesth 2003; 17(3): 314-20.

37. Castillo R, Rodrigo R, Pizarro R, Escobar M, Cereceda M, Asenjo R, et al. Nueva estrategia de preacondicionamiento no hipóxico que atenúa el efecto de la Isquemia-Reperfusión en pacientes sometidos a cirugía cardíaca con circulación extracorpórea. Revista chilena de cardiología 2009; 28:3144.

38. Zakkar M, Ascione R, James AF, Angelini GD, Suleiman MS. Inflammation, oxidative stress and postoperative atrial fibrillation in cardiac surgery. Pharmacol Ther 2015; 154:13-20.

39. Greenberg JW, Lancaster TS, Schuessler RB, Melby SJ. Postoperative atrial fibrillation following cardiac surgery: a persistent complication. Eur J Cardiothorac Surg 2017; 52(4): 665-72.

40. Eslami M, Badkoubeh RS, Mousavi M, Radmehr H, Salehi M, Tavakoli N, et al. Oral ascorbic acid in combination with beta-blockers is more effective than beta-blockers alone in the prevention of atrial fibrillation after coronary artery bypass grafting. Tex Heart Inst J 2007; 34(3): 268-74.

41. Rodrigo R, Korantzopoulos P, Cereceda M, Asenjo R, Zamorano J, Villalabeitia E, et al. A randomized controlled trial to prevent post-operative atrial fibrillation by antioxidant reinforcement. J Am Coll Cardiol 2013; 62(16): 1457-65.

42. Rho RW. The management of atrial fibrillation after cardiac surgery. Heart 2009; 95(5): 422-9. 